\title{
INTERPRETAÇÕES EVANGÉLICAS DO VATICANO II: NOTAS SOBRE UMA RECENTE PUBLICAÇÃO
}

\author{
Evangelical Interpretations of Vatican II: \\ Notes on a recent publication
}

\author{
Lubomir Zak* \\ Tradução do italiano: Antônio Dalpicol
}

\section{RESUMO}

O texto analisa a produção evangélica italiana feita no fascículo $X X V / 2$, n. 50 , da revista Studi di Teologia sobre o Vaticano II, onde constam seis textos que avaliam a doutrina conciliar. A análise foi elaborada sob a ótica evangélica por Pietro Bolognese e Leonardo de Chirico.

Palavras-chave: Vaticano II. Evangelicalismo italiano. Eclesiologia. Ecumenismo.

\section{ABSTRACT}

This text analyzes the Italian evangelical production made in the XXV/2 fascicle, n. 50, of the Studi di Teologia journal of the II Vatican, which contains six texts that evaluate the Council doctrine. The analysis was elaborated under the evangelical approach by Pietro Bolognese and Leonardo de Chirico.

Keywords: II Vatican. Italian Evangelicalism. Ecclesiology. Ecumenism.

* Docente habitual de Introdução à teologia e História da teologia junto à Faculdade de Teologia da Pontifícia Universidade Lateranense.

\begin{tabular}{|l|l|l|l|l|l|}
\hline Teocomunicação & Porto Alegre & v. 44 & n. 2 & p. 161-180 & maio-ago. 2014 \\
\hline
\end{tabular}




\section{Introdução}

O que pensam os evangélicos ${ }^{1}$ ("evangelicals") a respeito do Concílio Vaticano II, o que dizem sobre sua convocação e celebração, como interpretam o ensinamento e recebem dele os frutos?

É necessário admitir que até hoje os estudiosos católicos do Concílio têm prestado pouca atenção a essas e outras questões semelhantes, limitando-se a escutar, quase que exclusivamente, as numerosas vozes pronunciadas sobre a importância das assembleias conciliares pelos pastores, pelos teólogos e pelos históricos das igrejas e das históricas comunidades protestantes. ${ }^{2}$ Mas existem vários motivos que, desde muito tempo, empurram na direção de uma mudança de rota. Entre esses, sem dúvida, a crescente e influente presença do evangelicalismo em todos os continentes e a sua capacidade de "crescer" internamente e de "homologar" igrejas e comunidades pertencentes seja ao protestantismo histórico, seja à área cristã não protestante. Um outro motivo, mais específico, está na existência de estudos realizados pelos mesmos evangélicos com a intenção de oferecer uma análise e avaliação próprias da assembleia conciliar. Um dos últimos exemplos nesse

1 O termo "evangélico" e a realidade do "evangelicalismo" encontram-se explicados em P. BOLOGNESI, ver Evangelicalismo, em Dicionário de teologia evangélica (=DTE), aos cuidados de P. BOLOGNESI, L. DE CHIRICO e A. FERRARI, Editora Uomini Nuovi, Marchirolo, 2007, p. 263-265; encontra-se, também em K. THACKER - T. D. GENER, ver Evangelism, em W. A. DYRNESS - M.-M. KÄRKKÄINEM (eds.), Global Dictionary of Theology: A Resource for the Worldwide Church, InterVarsity press Academic, Downers Grove, 2008, p. 297-300. Permanecendo, além disso, na sintética descrição da identidade específica do cristianismo "evangélico", em La missione. Rapporto 1977-1984, publicado em Enchiridion Oecumenicum (= EO), vol. 3, EDB, Bolonha, 1995, p. 10271028 (original inglês: The Evangelical - Roman Catholic Dialogue on Mission [19771984]. A Report, ed. B. Meeking - J. Scott, Eerdmans, Grand Rapids 1986). A respeito da relação entre o evangelicalismo e o pentecostalismo e, em particular à debatida questão se os pentecostais são incluídos entre os evangélicos, veja-se o recente estudo, com foco no contexto norte-americano, de T. L. Cross, Sind Pfingstler evangelikale Chisten? Eine Betranchtung der theologischn Unterschiede undGemeinsamkeiten, em J. Haustein - G. Maltese (Hg.), Handbuch Pflingstliche und charismatische Theologie, Vandenhoech \& Ruprecht, Göttingen, 2014, p. 383-407. A posição de Cross é clara: “Os pentecostais fazem ora parte deste movimento [evangelicalismo - L. Z]? Sim. Os pentecostais são idênticos aos evangélicos? Não!" (Ibid., p. 391).

2 Tais referências começam a aparecer desde a abertura do Vaticano II, tratando inicialmente, sobretudo, das avaliações e das reflexões dos protestantes presentes à assembleia conciliar como observadores. Para uma breve apresentação de seu conteúdo, ver M. Hopf, Dialog unterwegs - Stimmer evangelischer Beobachter zur dritten. Session des Zweiten Vatikanischen Konzils (1964), p. 110-119 (pela bibliografia ver as notas n. 4-8, 12 e 24). 
campo, limitando-nos à produção feita "em casa pelo evangelicalismo italiano, ${ }^{3}$ é o recente fascículo monográfico da revista Studi di teologia, do Instituto de formação evangélica e documentação (IFED), sobre o tema Il Vaticano II in ottica evangélica. ${ }^{4}$ A presente nota pretende oferecer-nos um exame analítico.

O fascículo contém seis textos de tamanho variado que, juntos, compõem um pequeno, todavia significativo, mosaico através do qual se procura oferecer uma precisa e sobretudo "correta" avaliação teológica por parte dos evangélicos, da doutrina conciliar. Escrevo "correta" porquanto o objetivo dos idealizadores desta interessante iniciativa editorial está orientado não tanto ad extra, para informar os católicos das próprias interpretações do Vaticano II, mas principalmente ad intra, para oferecer aos cristãos evangélicos - e, in primis, aos pastores e teólogos - um juízo "oficial", formulado segundo os parâmetros das convicções partilhadas pelo evangelicalismo mundial.

É necessário acrescentar que, exceto um estudo crítico (Igreja na perspectiva católica e professante, p. 132-139), assinado por Pietro Bolognesi ${ }^{5}$ todas as outras contribuições do fascículo foram escritas por Leonardo De Chirico, diretor da revista Studi di teologia, docente do IFED e vice-presidente da Aliança Evangélica Italiana. É evidente que tal desequilíbrio não é outro que a lógica consequência do fato de que entre os evangélicos na Itália é mesmo De Chirico que se ocupa

3 Quanto por outro lado ao evangelicalismo mundial, cita-se o estudo da doutrina católicoromana, feito em referência ao Vaticano II, elaborado por um grupo de teólogos da Aliança evangélica mundial (= AEM) e publicado no documento Una valutazione evangélica del cattolicesimo romano, promulgado durante a assembleia geral do AEM, que se realizou em Singapura em 1986 (a tradução italiana foi publicada em Dichiarazione evangeliche. Il momento evangelicale 1966-1996, aos cuidados de P. Bolognesi, EDB, Bolonha, 1998, p. 265-315). Cf. L. De Chirico, Il Vaticano II, banco di prova dela teologia evangélica, em "Studi di teologia", XXV/2 (2013), n. 50, p. 105.

4 Cf. "Studi di teologia", XXV/2, n. 50; a sessão dedicada ao Concílio encontra-se nas páginas 97-155. Permanecendo no âmbito da produção evangélica italiana, veja-se também J. Ruiz, ver Vaticano II, Concilio, em DTE, p. 773-774. Por uma rápida apresentação e avaliação do DTE, do ponto de vista seja temático ou epistemológico, permito-me remeter à ampla resenha crítica publicada em "Lateranum", 76 (2010), p. 517-522.

5 Docente de teologia junto ao IFED (Pádua) e ao Institute of Reformed Baptist Studies junto ao Westminster Theological Seminary (Calofórnia), já membro da Comissão teológica do AEM (tem participado na elaboração da Declaração de Singapura), Bolognesi é um dos mais notáveis teólogos do evangelicalismo italiano. Recentemente publicou Tra credere e sapere. Della Riforma protestante all'Ortodossia riformata, Alfa \& Omega, Caltanisetta, 2011. Pelo seu trabalho de promoção da teologia evangélica na Itália, a Faculté Jean Calvin di Aix-en-Provence conferiu-lhe, em 2011, a láurea em teologia honoris causa. 
do estudo do catolicismo-romano e que está juntamente envolvido no diálogo ecumênico com a Igreja romana, tendo dado prova de apaixonado e constante interesse por esse campo de pesquisa teológica e ecumênica com a publicação do volume Evangelical Theological perspectives on Post-Vatican II Roman Catholicism (Peter Lang, Bern-Oxford, 2003). ${ }^{6}$

\section{As interpretações evangélicas do Concílio como problema}

É sobretudo o artigo O Vaticano II, banco de prova da teologia evangélica que coloca em evidência um dado talvez pouco ou nada conhecido pela teologia católica, isto é, que na conclusão dos trabalhos conciliares houve alguns teólogos evangélicos que tentaram examinar os resultados, "elaborando substancialmente três formas de leitura do Concílio".?

A primeira leva à seguinte conclusão: "Roma iniciou verdadeiramente um caminho "novo", inaugurando uma nova fase que pouco se assemelhará à anterior e muita coisa será diferente". ${ }^{8}$ Este método é usado pelo holandês Gerrit Berkouwer, ${ }^{9}$ único teólogo da "área evangélica" presente na sessão conciliar na qualidade de observador, autor da obra Vaticans Concilie em nieuwe theologie, editada em 1964 (pelos tipos da Kok, Kampen). ${ }^{10}$ Para Berkouwer, o Concílio operou um radical deslocamento de enfoques, promovendo uma inaudita abertura sem retorno, em particular na eclesiologia, repensada no âmbito da categoria bíblica do povo de Deus. Pelo parecer de De Chirico, essas conclusões do teólogo holandês pecam por uma superficialidade e parcialidade próprias de quem se tem deixado impressionar pela assembleia conciliar sem ter tido tempo suficiente para examinar a fundo o pensamento.

6 Merece ser assinalado também o site <www.vaticanfiles.org>, contendo análises, exposições e recensões de De Chirico sobre a realidade do catolicismo romano contemporâneo.

7 L. DE CHIRICO. Il Vaticano II, banco di prova, cit., p. 112.

8 Ibidem.

9 Da informação do teólogo holandês sobre o catolicismo romano se ocupa o recente estudo de E. ECHEVERRIA, Berkouwer and Catholicism. Disputed Questions, Brill Academic Publishers, Leiden - Boston, 2013. Para uma rápida apresentação da pessoa e da obra de Berkouwer, cf. a voz a ele dedicada no DTE, p. 87.

10 Tradução inglesa: The Second Vatican Council and the New Catholicism, Grand Rapids, Eerdmans, 1965. 
A segunda forma pode ser descrita nos seguintes termos: "Roma está profundamente dividida no seu interior e deve ainda decidir de que lado ficar: a tradição ou a atualização". ${ }^{11}$ Esse viés de leitura aparece na obra Revolução em Roma (InterVarsity Press, Downers Grove, 1972), de David F. Wells, professor no Gordon-Conwell Theological Seminary. Wells está convicto de que os argumentos do Concílio são heterogêneos e contraditórios: seriam usados para justificação de ideias, conceitos, pensamentos, englobando teologias incompatíveis entre si e constituindo uma espécie de complexio oppositorum. Mas como se pode colocar junto a teologia do Concílio de Trento com a do Vaticano I e a nouvelle théologie que inspirou o Vaticano II? Individualizando numerosas tensões internas, Wells prevê uma ruptura próxima do aparente equilíbrio da doutrina conciliar, e com ela o necessário posicionamento da Igreja de Roma a favor de um só dos numerosos polos de suas contraditórias posições.

Enfim, a terceira forma é caracterizada pela convicção de que "Roma é sempre a mesma e não mudará nunca". ${ }^{12}$ Esta é a posição de Herbert Carson, pastor britânico e autor de uma trilogia ${ }^{13}$ na qual examina, de forma crítica, a doutrina da Igreja de Roma e a herança do Concílio. No parecer de Carson, a Igreja de Roma, também quando se atualiza e produz novos textos doutrinais, é semper eadem na sua posição fundamental. A atualização de Roma "é na realidade uma camuflagem de uma identidade que permanece a mesma também se tenta, uma vez que outra, parecer apresentar-se de modo cosmeticamente dinâmico". ${ }^{14}$

Aquilo que surpreende não são as diferentes posições dos três métodos apresentados, mas sim a aceitação de De Chirico da importante utilização, no pós-concílio, do primeiro método interpretativo por parte dos teólogos evangélicos. Que tal presença represente um problema para o evangelicalismo, seja italiano ou mundial, vem reconhecido sem meios termos no artigo-nota Vittorio Subilia (1911-1988) e Fausto Salvoni (1907-1982), intérpretes do catolicismo pós-conciliar. ${ }^{15}$ Subilia e Salvoni são apresentados como vigilantes filhos da Reforma, inflexíveis

${ }^{11}$ L. DE CHIRICO. Il Vaticano II, banco di prova, cit., p. 112.

${ }^{12}$ Ibidem.

${ }^{13}$ Cf. Roman Catholicism Today, Inter-Varsity Fellowship, Londres, 1964; Dawn or Twilight? A Study of Contemporary Roman Catholicism, Inter-Varsity Press, Leicester, 1976; The Faith of the Vatican. A Fresh Look at Roman Catholicism, Evangelical Press, Darlington, 1996.

${ }^{14}$ L. DE CHIRICO. Il Vaticano II, banco di prova, cit., p. 111.

${ }^{15}$ Cf. L. DE CHIRICO. Vittorio Subilia (1911-1988) e Fausto Salvoni (1907-1982), intérpretes do catolicismo pós-conciliar, em "Studi di teologia", XXV/2 (2013), n. 50, p. 126-131. 
na sua competente crítica do catolicismo, emergido do Vaticano II, mas com pouca sorte, por não ter tido herdeiros à altura. $\mathrm{O}$ laboratório teológico por eles criado no pós-concílio tornou-se, de fato, árido, vindo menos da clarividência e da competência, e isso mesmo em tempos em que o catolicismo italiano dá sinais de uma nova vitalidade. E mesmo o espaçamento de uma parte da teologia evangélica - que teria sido causado pela falta de parâmetros em nível de ajudar a colher as reais dinâmicas teológicas do catolicismo gerado pelo Concílio - e, com isso, o perigo de um possível "redemoinho ecumênico" seu é um problema real e, certamente, não apenas italiano.

Isso se evidencia das contribuições de Igreja na perspectiva católica e professante, de Bolognesi, e de $\mathrm{O}$ apelo sacramental entre fascinação e ingenuidade, de De Chirico, em que se fala de dois exemplos concretos de pouca aceitação por parte dos teólogos evangélicos frente à insidiosa teologia católico-romana: o volume L'Église comme communion et comme instituition. La lecture de l'ecclesiologie du cardinal Congar à partir de la tradition des Églises de professants (Cerf, Paris, 2012) de Alain Nisus, ${ }^{16}$ pastor batista e professor de teologia sistemática na Faculdade Livre de Teologia Evangélica (Vaux-sur-Seine), e os volumes Nouvelle Théologie and Sacramental Ontology. A Return to Mystery (OUP, Oxford, 2009) e Heavenly Participation. The Wearing of a Sacramental Tapestry (Eerdmans, Grand Rapids, 2011) de Hans Boersma, ${ }^{17}$ professor no Regent College di Vancouver. Referindo-se aos dois últimos volumes, De Chirico constata:

Estes livros são um testemunho de como a teologia evangélica, em confronto com o catolicismo pós-conciliar, pode assumir altos níveis de erudição e de sofisticação (a ponto de merecer a publicação junto a editores de prestígio), sem por isso ter desenvolvido um adequado conhecimento das questões debatidas. Junto a observações inteligentes e pontuais, encontram-se deslizes perigosos que refletem uma puberdade teológica não plenamente alcançada (...) O confronto com a nouvelle théologie é necessário para estabelecer uma relação com a dinâmica do catolicismo pós-conciliar, mas da parte evangélica isso é ensinado com uma maturidade teológica decisivamente diferente. ${ }^{18}$

\footnotetext{
${ }^{16}$ Cf. P. BOLOGNESI. Chiesa in prospettiva católica o professante, em "Studi di teologia", XXV/2 (2013), n. 50, p. 132-139.

${ }^{17} \mathrm{~L}$. DE CHIRICO. Il richiamo sacramentale tra fascinazione e ingenuità, em "Studi di teologia", XXV/2, n. 50, p. 141-143.

${ }^{18}$ Idem, p. 142-143.
} 
No centro da disputa está, pelo parecer de Bolognesi e De Chirico, a necessidade de reconhecer que o Vaticano II e a sua herança doutrinal não são outra coisa que a última versão - a mais atualizada - da mesma e idêntica realidade chamada "catolicismo", considerado como um complexo e, porém, unitário "sistema" (feito de ritos, piedade popular, espiritualidade, normas canônicas, doutrinas dogmáticas e morais, teologias) para identificar-se com a Igreja católica de Roma. Em consequência, não são o Vaticano II e a sua herança doutrinal que devem ser assunto como critério de interpretação do catolicismo pósconciliar, mas é o "catolicismo" romano em si, ou seja, o "sistemacatolicismo", ${ }^{19}$ que deve fazer as funções de prisma hermenêutico para entrever claramente o verdadeiro significado de todo o evento conciliar e de cada uma de suas afirmações.

\section{O Vaticano II e o sistema denominado "catolicismo"}

Mas, nos documentos conciliares, onde estão visíveis as influências deste perene e inatacável "sistema"? Onde se encontra instalado o "catolicismo"? A resposta vem imediatamente através do Documento de Singapura ${ }^{20}$ do AEM, onde são analisadas nove esferas de alta problematicidade teológico-doutrinal, entre as quais: o conceito católico-romano de "Igreja" e de "liberdade religiosa", a assim denominada "mariolatria" dos católicos romanos, a autoridade da Escritura colocada abaixo da Tradição, o papado, a infalibilidade papal e ainda outras. De Chirico, no texto Os documentos do Vaticano II. Questões e temas abertos, quer ser ainda mais explícito, chamando a atenção sobre aqueles nós problemáticos dos dicta dos documentos conciliares que mais interpretam a teologia evangélica, suscitando interrogações, perplexidade e incertezas. Ele assinala e problematiza asserções como:

${ }^{19} \mathrm{O}$ que se possa entender aqui sobre "catolicismo" já vem explicado de modo conciso em P. Bolognesi, na obra Cattolicesimo, em DTE, p. 119-121. O termo "sistema" não é utilizado por acaso. Como reafirma o documento Orientamenti evangelici per pensarei il catolicesimo (1999) dell'IFED: Cada proposta que não destaque o fato de que o catolicismo é um sistema, presta-se para uma análise fragmentária e desemboca numa compreensão superficial" ( n. 1); o documento encontra-se em <http://www.alleanzaevangelica.org/ documenti/orientamenti_cattolicesimo.htm> (18 ago..2014).

${ }^{20}$ Cf. Una valutazione evangélica del caltolicesimo romano, em Dichiarazioni evangeliche, cit., p. 312-374. 
Da Liturgia e, particularmente, da Eucaristia, nasce em nós, como da própria nascente, a graça (SC 10); ‘(...) A Comunhão, sob as duas espécies, pode-se conceder' (SC 55); 'A Santa Igreja venera com particular amor Maria Santíssima, mãe de Deus' (SC 103); 'Participando do sacrifício eucarístico (...) Ofereceu a Deus a Vítima divina' (LG 11); 'Os livros da Escritura ensinam, com certeza, fielmente e sem erro, a verdade de Deus, em direção à nossa salvação' (DV 11); 'Só por meio da Igreja católica de Cristo (...) pode-se obter a plenitude dos meios de salvação' (UR 3); 'A Igreja (...) adverte de maneira urgente a própria vocação de salvar e de renovar cada criatura' (AG 1); e, ainda, muitas outras. ${ }^{21}$

Analisando essa e outras contribuições de De Chirico, nota-se a convicção do teólogo evangélico de poder reconduzir todas as partes problemáticas dos documentos do Concílio a um único denominador feito de algumas ideias fundamentais e, indubitavelmente, sistemáticas do catolicismo. Entre elas está aquela de um "sacramentalismo eclesial segundo o qual é a igreja que media a sua instituição sacramental". ${ }^{22}$ Já Subilia considerou esse tipo de eclesiologia soteriológica como uma espécie de "encarnacionismo eclesiológico", ${ }^{23}$ que vê a igreja como continuação da encarnação, atribuindo-lhe, deste modo, "indevidamente, as prerrogativas dos ofícios real, profético e sacerdotal de Cristo". ${ }^{24}$

Esse mesmo tipo de eclesiologia e teologia sacramental começa a fascinar, hoje, teólogos evangélicos como Nisus, Boersma e outros, todos pouco atentos aos erros de fundo do sacramentalismo católicoromano. Segundo parecer de De Chirico, tal "abaixamento de guarda" é gerado pela situação na qual versa uma parte da atual teologia

${ }^{21}$ L. DE CHIRICO. I documenti del Vaticano II. Questioni e temi aperti, em "Studi di teologia", XXV/2 (2013), n. 50, p. 151-155.

${ }^{22}$ L. DE CHIRICO. Il Vaticano II, banco di prova, cit., p. 115. Bolognesi - convencido também ele da existência de alguns elementos unificadores, de valor sistêmico, do "catolicismo" - reassume tais ideias embasado em duas linhas teológicas determinadas pelas noções de "revelação" e de "mediação" e dá uma interpretação católico-romana das mesmas (P. BOLOGNESI, em Cattolicesimo, cit., p. 119).

${ }^{23}$ Cf. L. DE CHIRICO. Vittorio Subilia (1911-1988) e Fausto Salvoni (1907-1982), cit., p. 127. Aprofundando mais a mesma crítica, Bolognesi escreve: "A ideia de mediação do catolicismo manifesta, enfim, uma tendência monofísica. A causa da encarnação continuada que se realiza no sacrifício da missa, é a distância entre o Criador e a criatura que desaparece. A encarnação continuada faz ressurgir o papel do Espírito Santo e apresenta a igreja enquanto mediadora entre Deus e o homem" (P. BOLOGNESI, em Cattolicesimo, cit., p. 120).

${ }^{24}$ L. DE CHIRICO. Vittorio Subilia (1911-1988) e Fausto Salvoni (1907-1982), cit., p. 127. 
evangélica que, nascida em uma época neofundamentalista, está "toda centrada nas lutas pela verdade evidente, pela certeza do acreditar, pela consciência sobre os detalhes (...) a árida e despojada pobreza objetiva do neofundamentalismo encontra na teologia católica atual, assim arejada, esfumada, intrigante, alguma coisa semelhante a uma lufada de ar fresco para respirar a plenos pulmões". ${ }^{25}$

A ideia do "sacramentalismo eclesial", como também todas as outras ideias sistemáticas do "catolicismo" romano, seria fruto de escolhas precisas de caráter epistêmico, as quais - todavia dando a impressão, em certos casos, de ter um peso e uma incidência menor - diferenciam-se, também se contradistinguem, radicalmente, a hermenêutica da teologia evangélica daquela da teologia católico-romana. Tal diferenciação vem acertada e reconhecida já pelos participantes do primeiro diálogo bilateral católico-evangélico - desenvolvido nos anos de 1977-1984 - ${ }^{26}$ os quais entreveem uma das suas principais causas na diferente consideração da Sagrada Escritura. ${ }^{27}$ De fato, no Rapporto final, lê-se que os católicos e os evangélicos "têm uma concessão levemente diferente da natureza da Escritura e uma concessão fortemente diferente do justo processo de interpretação da palavra de Deus". ${ }^{28}$ Levemente diferente porque,

${ }^{25}$ L. DE CHIRICO. Il richiamo sentimentale tra fascinazione e ingenuità, p. 140. E ainda: "A teologia sacramental do catolicismo atual é o "coração do catolicismo e compreende-se como se pode atrair ambientes que se nutrem de generalizações de imaginários teólogos pobres e áridos. Em vez de reapropriar-se da "grande tradição" da fé cristã clássica (bíblica, patrística, reformada, reavivada, evangélica), contentam-se com uma visão persuasiva que abre para a síntese católico-romana" ( Idem, p. 143).

${ }^{26}$ Trata-se de um diálogo (sobre o tema "missão") patrocinado pela formação da unidade dos cristãos, ao qual aderiram alguns importantes missionários e teólogos evangélicos (como John Stott), mas não a World Evangelical Fellowship, nem alguma outra instituição representativa evangélica. Recorde-se que nos anos de 1993-2002 uma segunda jornada dos diálogos católico-evangélicos, esta vez patrocinada oficialmente por ambas as partes, dedicada ao tema Chiesa, evangelizzazione e vincoli di koinonia. Cf. o Rapporto 19932002, em EO, vol. 7, EDB, Bolonha, 2006, p. 1681-1780; veja-se também o comentário sobre o Rapporto feito pelo bispo neozelandês B. Meeking, em EO, p. 1781-1830 (o texto original do Rapporto e do comentário encontra-se no site-web do Pontifício Conselho pela formação da unidade dos cristãos).

${ }^{27}$ Para uma rápida apresentação da concessão evangélica da Escritura, veja-se J. I. PACKER, em Scrittura, em DTE, p. 658-663; L. DE CHIRICO, em Autorità dela Scrittura, em DTE, p. 71-73; Id., em Critica biblica, em DTE, p. 165-166; I. HOWARD MARSHALL, em Interpretazione bíblica, em DTE, p. 362-364, com a respectiva bibliografia. De útil leitura, sobre o mesmo argumento, também o periódico monográfico Studi di teologia (XXIV/1 [2012], n. 47) sobre o tema La Bibbia al centro (veja-se particularmente G. Williams, Le convinzioni evangeliche in torno alla Scrittura, p. 4-27).

${ }^{28}$ Rapporto 1977-1984, p. 1045. 
enquanto os católicos estão habituados a considerar a Escritua na sua complexidade de Palavra de Deus escrita por autores humanos, uma realidade inscrita na lógica da Encarnação, os evangélicos preferem dar destaque na obra providencial de Deus, não obstaculizada pelos limites dos seres decadentes. Fortemente diferente porque os católicos, diferentemente dos evangélicos, afirmam que "a escritura é considerada como produzida pela igreja e na igreja" e que, depois, não é possível "compreender a Escritura na sua verdade a não ser que a recebam na fé viva da igreja, a qual, assistida pelo Espírito Santo, mantém-se na obediência à palavra de Deus". ${ }^{29}$ Entende-se que, no centro da diferente consideração da Escritura por parte dos católicos e dos evangélicos está a consideração radicalmente divergente da questão da legítima e necessária existência, junto à Escritura, de uma instância interpretativa "externa" (não idêntica à mesma Escritura nem à pessoa que a lê) e objetiva em grau de garantir aquele amplo consenso ao qual convida com insistência Paulo em 1Cor 1,10. E é evidente que tal questão coincide com a pergunta sobre a legitimidade a respeito da necessidade, para $\mathrm{o}$ acreditar e o interpretar a Escritura, da realidade chamada "tradição"30 (para não falar, depois, da instância chamada "magistério"). ${ }^{31}$

\footnotetext{
${ }^{29}$ Ver p. 1048. Segundo os evangélicos, em vez, “é sábio escutar a igreja e os seus mestres, passados e presentes, e levar em conta o modo como eles procuram compreender a Palavra de Deus", todavia eles "enfatizam o fato de que cada crente deve ser livre para exercitar a própria responsabilidade pessoal diante de Deus no ouvir e obedecer a sua Palavra. Também se as interpretações da igreja são muitas vezes úteis, em última análise, não são necessárias, desde o momento em que a Escitura, sob a iluminação do Espírito Santo, interpreta-se a si mesma e é evidente (clara)" (ver p. 1049). A diferença entre os evangélicos e os católicos romanos em matéria de Escritura vem, no Rapporto 1977-1984, remarcada também em relação ao "grau no qual o sentido espiritual pode ser separado do sentido literal". (ver p. 1134).

${ }^{30}$ Como se observa, os evangélicos temem que os tradicionais eclesiásticos possam ocultar a palavra de Deus, enquanto os católicos temem que ela possa perder-se na multiplicidade de interpretações mais ou menos excêntricas" (Rapporto 1977-1984, cit., p. 1070). O temor dos evangélicos e as suas perplexidades em frente ao recurso interpretativo dos católicos à "tradição" não se delega nem mesmo em contato com a Dei verbum do Vaticano II. Como vem escrito desde o Documento de Singapura, se de um lado é verdade que o Concílio se empenhou em apresentar mudanças em relação a uma maior centralidade da Escritura na Igreja, ele, por outro lado, não resolveu um problema fundamental, isto é, que "quando se trata da questão da autoridade, a Igreja católico-romana reserva para si mesma, como instituição, um poder que, segundo o ensinamento oficial, está subordinado à Escritura, mas que, na prática, é superior a ela, em última análise" (Una interpretazione evangélica dell cattolicesimo romano, cit., p. 334).

31 Sobre a diferente consideração do "magistério", cf. Rapporto 1977-1984, cit., p. 1070-1075 como também Una valutazione evangélica dell cattolicesimo romano, cit., p. 328-336.
} 
Mas o problema do sistema "catolicismo" é, pelo parecer dos evangélicos, ainda mais profundo e insidioso. Ele é determinado e alimentado pelo mesmo espírito do "catolicismo" romano, pela sua intencionalidade de fundo e pela sua orientação geral, pelo espírito, intencionalidade e orientação que fazem do catolicismo um sistema extremamente ambíguo, porque capaz - também desejoso - de incluir e de absorver em si qualquer possível diferença. Possuindo tal espírito, a doutrina e a teologia católicas estão "em grau de inclinar-se, mas não de curvar-se" 32 e isso explica por que a forma mentis católico-romana não é "aquela da escolha feita para excluir, mas aquela da escolha elíptica que catoliciza". ${ }^{33}$

Pois bem, esse mesmo tipo de forma mentis possui também o Vaticano II, um concílio que lança novamente o mesmo e idêntico sistema doutrinal do passado, no qual "a natureza vem junto com a graça, a Escritura com a Tradição, Cristo com a Igreja, a graça com os sacramentos, a fé com as obras, a vida cristã com a religião popular, a piedade evangélica com o folclore pagão, a filosofia especulativa com a crenças supersticiosas, o centralismo eclesiástico com o universalismo católico". ${ }^{34}$ Enfim, explica Di Chirico, o Concílio não faz mais que afirmar obstinadamente et.-et, e-e, uma coisa e outra." Por isso:

Não há escolhas límpidas, nítidas, exclusivas ou inspiradas numa integridade de pensamento capaz de escolher de modo coerente. Ao contrário, a capacidade receptiva católica produz o catolicismo como um sistema sempre aberto a novas integrações em vista da crescente expansão do próprio sistema. O critério teológico de fundo do catolicismo não é a pureza evangélica ou a autenticidade cristã, mas a integração do particular num horizonte universal a serviço da instituição que tem as rédeas de todo o desenho. O único "não" que o catolicismo sabe dizer refere-se àquilo que ameaça o seu objetivo que quer reconduzir o múltiplo ao uno da Igreja católica. Quando esse fundamento não é colocado em discussão, tudo pode ser integrado e catolicizado. A capacidade de integração

\footnotetext{
${ }^{32}$ L. DE CHIRICO. Il Vaticano II, banco di prova, cit., p. 104. O mesmo juízo é encontrado em P. BOLOGNESI, em Cattolicesimo, cit., p. 120, e antes ainda em Orientamenti evangelici per pensare il cattolicesimo, cit., nn. 3-5.

${ }_{33}^{3}$ L. DE CHIRICO. Il Vaticano II, banco di prova, cit., p. 110.

${ }^{34}$ Ver p. 120; P. BOLOGNESI em Cattolicesimo, cit., p. 120.
} 
do catolicismo, os seus recursos absorventes são verdadeiramente extraordinários. ${ }^{35}$

Das contribuições de De Chirico se deduz que são dois os eixos fundamentais em torno dos quais gira e por meio dos quais se mantém vivo e se difunde o espírito do "catolicismo" romano: a ideia infundadamente generosa e otimista da salvação de todos os homens (sem distinção alguma); a formidável capacidade de adaptação camaleônica e oportunista da linguagem doutrinal e teológica da Igreja romana às exigências do diálogo - não privado de perigosas tendências proselitistas - com os outros cristãos e com as outras religiões.

Quanto ao primeiro aspecto, os evangélicos, por um lado, "insistem sobre o fato de que, segundo o Novo Testamento, todos aqueles que não estão com Cristo estão "perdidos" e podem conseguir a salvação só em e através de Cristo", ${ }^{36}$ por outro lado, estão convencidos de que os católicos propõem uma doutrina sobre a salvação que não corresponde com os ensinamentos da Escritura, porquanto ignora a gravidade das consequências do pecado de Adão e a condição da natureza depravada. ${ }^{37}$ Pelo parecer de De Chirico, tal tomada de posição dos católicos impõe-se com o Vaticano II. Se, então, a doutrina católica tradicional excluía os não católicos da salvação, o Concílio afirma que também esses estão, de qualquer modo, unidos com Cristo, "quer o queiramos ou não". ${ }^{38}$ A gravidade de tal mudança aumenta pelo fato de que a universalidade da salvação, propugnada pelo ensinamento conciliar, "vem junto ao particularismo da igreja". ${ }^{39}$ O quadro final não deve enganar: a catolicidade do catolicismo pósconciliar transcende os confins um pouco exíguos da cristianidade, tanto que se precisa afirmar: "A cristianidade, as religiões, a cultura,

${ }^{35}$ L. DE CHIRICO. Il Vaticano II, banco di prova, cit., p. 120-121. A mesma crítica é encontrada no documento do IFED: "O catolicismo é mestre em assimilar no próprio sistema elementos diversos, às vezes, contrastantes, muitas vezes, opostos. O critério não é o da pureza evangélica ou da autenticidade cristã, mas aquele do englobamento progressivo e dda integração do particular numa perspectiva ampla que lhe anula a unilateralidade e o coloca a serviço da universalidade" (Orientamenti per pensare il cattolicesimo, cit., n. 4).

${ }^{36}$ Rapporto 1977-1984, cit., p. 1125.

${ }^{37}$ Cf. P. BOLOGNESI, em Cattolicesimo, cit., p. 120.

${ }^{38}$ L. DE CHIRICO. Il Vaticano II, banco di prova, cit., p. 122.

${ }^{39}$ Ver p. 122-123. 
a sociedade, o mundo inteiro: essas são as fronteiras do catolicismo católico". ${ }^{40}$

O segundo aspecto é constituído pela habilidade do "catolicismo" de mudar as formulações doutrinais, sem querer "subir o degrau das prerrogativas absolutistas acumuladas através dos séculos". ${ }^{41}$ Assim, a partir do Vaticano II, Roma não usa mais a linguagem áspera, intrincada, difícil, cortante, aridamente jurídica dos concílios e dos pontífices anteriores, mas recorre a uma linguagem sinuosa, envolvente, inclusiva, amigável, materna, dinamicamente sacramental. Todavia, as verdadeiras intenções da Igreja romana pós-conciliar são as mesmas de antes: conduzir a todos sub Petro, integrar toda a cristandade no catolicismo, "que é e permanece visceralmente romano, papal, mariano, vaticano". ${ }^{42}$

De Chirico não tem nenhuma dúvida: a presença dos dois aspectos é o que caracteriza a sustentação do Vaticano II. Por consequência, não obstante "todas as suas boas intenções de renovação, o Concílio restituiu ainda mais elástica, extensa e acolhedora a plataforma da catolicidade do catolicismo, sem afrontar a questão fundamental", sem interrogarse sobre a verdadeira catolicidade, aquela bíblica, a que "não está na dialética entre "sim" e "não", gestada por uma instituição eclesiástica,

\footnotetext{
${ }^{40}$ Ver p. 123. E explica ainda: "Numa metáfora militar, pode-se dizer que a tática da catolicidade do catolicismo não é mais aquela do "confronto frontal" mas do envolvimento das partes. O objetivo não é mais o alienamento do adversário, mas o seu englobamento. O fim não é mais a conquista, mas sim a anexação consensual através da dilatação dos confins da catolicidade. A catolicidade não se exprime somente na doutrina católica, mas em todos os âmbitos da ação da Igreja. As suas fronteiras são tantas quantas são as dimensões da realidade. Tudo retorna novamente à jurisdição da catolicidade e a Igreja católica procura investir no crescimento de catolicidade" (L. DE CHIRICO. Vittorio Subilia [1911-1988] e Fausto Salvoni [1907-1982], cit., p. 130). Cf. P. BOLOGNESI, Chiesa in prospettiva cattolica o professante, cit., p. 133-134. É oportuno recordar que uma interpretação semelhante das intenções e da doutrina do Vaticano II está muito presente também no mundo da Ortodoxia, onde está difundida a convicção de precisar invadir o ponto nascente e a alma de tais intenções e doutrina na interpretação das "tendências liberais" de um grupo de padres e de peritos conciliares convencidos da necessidade de avizinhar a Igreja, a qualquer custo, da sociedade moderna e do seu "espírito de progresso". Cf. D. E. PUCKIN, em Vatikanskij II Sobor: "Duch Sobora" $i$ ego vlijanie na katolicestvo [Concílio Vaticano II: o Espírito do Concílio e a sua influência sobre o catolicismo], em Pravoslavnaja Enciklopedija [Enciclopedia Ortodoxa, aos cuidados do Patriarca de Moscou, versão eletrônica referida em < http://www.pravenc.ru/text/149919.html> (18.08.2014); M. Koslov, Cem dlja nas cenen opyt reform katoliceskoj Cerkvi? [Onde está o valor, para nós, da experiência das reformas da Igreja católica?], obra publicada no site oficial do Patriarcado de Moscou <http://www.patriarchia.ru/db/print/638670.html> (18.08.2014).

${ }^{41}$ L. DE CHIRICO. Il Vaticano II, banco di prova, cit., p. 118.

${ }^{42}$ Ver p. 122.
} 
mas na escolha por um reconhecer, aderir e servir o "sim" pleno do Evangelho". ${ }^{43}$

\section{O Vaticano II: continuidade na aparente descontinuidade}

Um tema recorrente em várias contribuições do fascículo diz respeito à questão da continuidade e/ou descontinuidade do Vaticano II em relação à tradição católico-romana anterior. Pelo que foi explicado, emerge que o evangelicalismo, na versão de De Chirico e Bolognesi, reconhece a existência de uma certa descontinuidade, mas não de substância, e sim de forma. E se entende imediatamente que não se trata, em cada caso, da versão evangélica da solução que sobre a questão da continuidade-descontinuidade tem oferecido Bento XVI, falando da hermenêutica da forma, ou seja, "da renovação na continuidade do único sujeito-Igreja." 44

Por um lado, de fato, não se nega que o Vaticano II tenha inaugurado algumas relevantes "novidades", sinalizando uma "mudança de rumo" e dando início a "profundas transformações". ${ }^{45}$ Tais novidades, mudanças de rumo e transformações dizem respeito substancialmente, como foi há pouco explicado, ao "estilo" dinâmico, por nada inquisitório da justificação doutrinal e da apresentação da "catolicidade" romana por parte do Vaticano II e da sua atuação pós-conciliar, um estilo claramente "diferente daquele dos concílios que o tem precedido". ${ }^{46}$ Referem-se, no entanto, também à mudança, considerada "radical", da concessão da Igreja de Roma nos confrontos dos cristãos não católicos e dos seguidores de outras religiões. Não vem explicado, nas contribuições do fascículo se, a respeito de tal nova situação há ao menos também uma real e radical mudança da doutrina católico-romana em matéria de soteriologia. Do modo que for, os autores dão por pressuposto que todas essas e outras mudanças - incluídas as doutrinais - serão possíveis graças à flexibilidade do sistema "catolicismo", capaz de uma permanente

\footnotetext{
${ }^{43}$ Ver p. 125. E explica ainda: "De fato, no catolicismo se assiste a uma ambiguidade de fundo entre a afirmação contemporânea do "sim" e do "não" e o Evangelho, que vêm referido no interior do sistema. Isso determina a coexistência de motivos bíblicos e de motivos não bíblicos" (ver p. 123).

${ }^{44}$ BENEDETTO XVI. Discorso alla cúria romana per la presentazione degli auguri natalizi, em "AAS", 98 (2006), p. 46.

${ }^{45}$ Cf. L. DE CHIRICO. Il Vaticano II, banco di prova, cit., p. 99, 121,122.

${ }^{46}$ Idem, p. 117.
} 
atualização e autodesenvolvimento que não pode não determinar cada aspecto da fé e da doutrina.

Eis porque, por outro lado, o Vaticano II não é visto como um concílio de radical descontinuidade, e tanto menos se pode falar de um concílio reformador ou revolucionário. Com certeza, não se trata de um concílio "fotocópia que foi mecanicamente e passivamente reproduzido visto que o catolicismo existia já antes que fosse celebrado", ${ }^{47}$ todavia ele é como os dois concílios anteriores, os quais serviram à causa do sistema "catolicismo" da sua defesa e difusão, salvaguardando a continuidade de tal sistema por meio de um megatrend "iniciado com a contrarreforma e consignado por uma inflexibilidade polêmica contra o protestantismo e a modernidade". ${ }^{48}$ No início de tal situação, está o Concílio de Trento, que rejeitou as instâncias da Reforma sobre a justificação somente pela graça e somente mediante a fé, decretando a sua incompatibilidade com a doutrina da Igreja católica e a indisponibilidade de Roma em empreender um percurso de radical revisão sob uma ótica bíblica. Esse mesmo concílio "é visto como pano de fundo, sem o repensar", ${ }^{49}$ do Vaticano II. Alguma coisa semelhante se pode dizer do Vaticano I, mas com uma diferença: o Vaticano I não conseguiu desenvolver plenamente a estratégia do "catolicismo", por isso precisava de um outro concílio que o retomasse, levando a Igreja de Roma junto ao mundo moderno a uma fase diferente, "mais dialógica, mais acessível para ouvir, menos exageradamente autorreferencial, menos opositiva, mais acolhedora" ${ }^{50}$ O Concílio Vaticano II teve exatamente essa tarefa.

É evidente que tal interpretação da continuidade existente entre o Vaticano II e os dois concílios anteriores apoia-se sobre os fundamentos da avaliação de Trento como concílio errôneo e danoso e o Vaticano I como concílio extremamente unilateral, mas, na sua essência, este também hostil a cada manifestação da Reforma protestante. O problema central é reapresentado a partir de Trento, o ponto inicial do sistema

\footnotetext{
${ }^{47}$ Idem, p. 113

${ }^{48}$ Ibidem

${ }^{49}$ Ibidem. "Trento permanece na moldura do Vaticano II, também, se neste último concílio, são as instâncias da modernidade que estão presentes junto às de Trento. $\mathrm{O}$ "paradigma tridentino" vem por assim dizer estoricizado e a Trento sobrevêm os desafios que a igreja vive nos século XX. Depois do Vaticano II, Trento deve ser lido à luz do último Concílio que oferece uma hermenêutica atualizada de sua teologia. De fato, porém, o Vaticano II metabolizou Trento e não o renegou" (ver, p. 113-114). Conforme a sintética avaliação do Concílio em L. DE CHIRICO, Trento, Concilio di, em DTE, p. 754.

${ }^{50}$ L. DE CHIRICO. Il Vaticano II, banco di prova, cit., p. 114.
} 
"católico", fruto de uma recusa radical da renovação da Igreja de Roma, da sua doutrina e de seu aspecto institucional à luz da Sagrada Escritura. A culpa do Vaticano II é de não ter declarado oficialmente que Trento estava superado, de não ter "pagado algum preço teológico para mudar o estilo: nenhuma desaprovação, nenhuma autocrítica, nenhum reconhecimento de pecado". ${ }^{51}$ Em síntese, a dinâmica fundamental do Vaticano II "não quis ser e não foi empurrada por uma reforma de sentido bíblico que consiste em arrependimento do pecado, purificação da idolatria e partilha no caminho da obediência ao Senhor". ${ }^{52} \mathrm{O}$ fato é, explica Bolognesi, que só pode haver uma verdadeira renovação "quando se reconhecem os erros anteriores", o cancelamento dos quais não se obtém mais com o recurso da lógica ecumênico-católica da "dilatação". Para falar de verdadeira mudança, é necessário medir a distância daquilo que se tem anteriormente afirmado. Se isso não advém, pode-se falar somente de extensão de pensamento, não de uma transformação". 53

\section{Conclusão: questões abertas}

Para um leitor católico do fascículo, pergunta-se espontaneamente quanto representativas são as interpretações, aqui presentes, do Vaticano II, quanto, pois, são compartilhadas no vasto mundo do evangelicalismo. Uma primeira resposta foi dada há alguns meses, por ocasião da apresentação do fascículo junto à Faculdade Pentecostal de Ciências Religiosas de Aversa. Após a mesa-redonda sobre o tema $\mathrm{O}$ catolicismo contemporâneo: uma perspectiva evangélica, promovida pela Aliança evangélica italiana, Federação das igrejas pentecostais, Assembleias de Deus na Itália, Igreja apostólica na Itália e Congregações cristãs

\footnotetext{
${ }^{51}$ Idem, p. 118.

${ }^{52}$ L. DE CHIRICO. Cosa è realmente accaduto al Vaticano II?, em "Studi di teologia" XXV/2 (2013), n. 50, p. 149. Com palavras semelhantes exprime-se também o Documento de Singapura do AEM, quando afirma: "Há uma grande fermentação nos ambientes católicos romanos, e o quadro está longe de ser claro. Em certos momentos, alegramo-nos porque parece que tenha iniciado um movimento de retorno à fé apostólica, mas depois ficamos consternados porque novamente o Evangelho vem eclipsado e tornado confuso. Às vezes parece que tudo esteja mudando, mas depois, por fim, nada muda. E em cada caso está claro que o catolicismo romano torna-se incapaz de dar uma resposta às questões centrais emersas da reforma" (Una valutazione avangelica del cattolicesimo romano, cit., p. 307).

${ }^{53}$ P. BOLOGNESI. Chiesa in prospettiva cattolica o professante, cit., p. 136.
} 
pentecostais, os representantes de todas essas organizações publicaram um breve comunicado ${ }^{54}$ que propõe de novo exatamente o mesmo método de leitura e as mesmas e idênticas críticas sobre as quais se apoiam as referidas reflexões relacionadas ao Vaticano II. Concretamente, eles afirmam considerar incompatível com o ensinamento da Escritura "uma igreja que se sente mediadora da salvação e que apresenta outras figuras como mediadoras de graças (...), uma igreja que assumiu a responsabilidade de juntar dogmas (como aqueles marianos) à fé uma vez e sempre transmitida aos santos (...), uma igreja que tem seu coração numa situação política, herança de uma igreja "imperial” da qual assumiu títulos e prerrogativas". Dito isso, o documento reafirma com convicção:

Portanto creem [os evangélicos italianos - L. Z.] que as aparentes semelhanças com a fé e a espiritualidade evangélica de setores do catolicismo não são de per si motivos de esperança de uma verdadeira mudança. Considerando que permanecem, a toda hora, diferenças teológicas e éticas inconciliáveis e absolutamente divergentes, não creem poder dar início e seguimento a qualquer iniciativa ou abertura ecumênica nos confrontos da Igreja Católica Romana, convidando a todos os evangélicos em nível nacional e internacional a exercitar um sadio discernimento bíblico (1Gv 4,1) sem ceder a desejos unificadores contrários à Escritura, mas também renovando a intenção de levar o Evangelho de Jesus Cristo para todo mundo (Mt 28, 18-20).

Uma segunda resposta, decididamente menos unívoca, foi possível captar por ocasião da visita do papa Francisco à comunidade pentecostal de Caserta. Refiro-me, por um lado, à reação crítica por parte de Bolognesi, de De Chirico ${ }^{55}$ e, sobretudo, por parte da Aliança evangélica italiana, ${ }^{56}$ apoiada na convicção da presença de obstáculos insuperáveis para que se possa realizar o diálogo com a Igreja católicoromana, devido à falta seja de centralidade da Palavra de Deus na sua doutrina e práxis, seja de uma aceitação dos erros do passado, originados na infidelidade nos confrontos do Evangelho de Cristo; por outro lado,

\footnotetext{
${ }^{54}$ Cf. Evangelici italiani sul cattolicesimo contemporâneo (19 de julho de 2014), consultável no site-web da Aliança evangélica italiana: <http:/www.allianzaevangelica.org/ cattolicesimo-romano/2014-03 cattolicesimo_trotonda.pdf $>$ (18 ago. 2014).

55 Veja-se a entrevista de 29 de julho concedida a De Chirico e a entrevista de $1^{\circ}$ de agosto a Bolognesi, ambas encontradas no site-web da Allianza evangélica italiana <http://www. allianzaevangelica.org/>.
} 
pelo fato de que o evento da visita do papa tenha suscitado a participação de uma numerosa delegação do AEM e que alguns de seus membros tenham feito comentários apreciativos sobre a pessoa e sobre o discurso do papa, compartilhando o espírito de abertura ecumênica de Giovanni Traettino, pastor da comunidade pentecostal de Caserta. ${ }^{57} \mathrm{O}$ evidente contraste entre as duas interpretações da visita do papa assinala que o mundo evangélico não possui um pensamento e uma atitude unívocos no que diz respeito à Igreja católico-romana, assim como existem em relação ao Vaticano II. O fascículo objetiva expor somente uma linha interpretativa, ${ }^{58} \mathrm{sem}$, porém, tomar em profunda consideração as razões e o discernimento teológico-espiritual daqueles teólogos e pastores e daquelas comunidades evangélicas que recorrem a interpretações diferentes. É de se ver, se no mundo evangélico, se instaurará um amplo confronto em vista da procura de um consenso interno, livre de prejuízos confessionais e acolhedor em relação às intenções e ao esforço de renovação da Igreja católico-romana.

Malgrado a unilateralidade da perspectiva interpretativa das contribuições do fascículo e, por consequência, a parcialidade dos juízos críticos aqui presentes em relação ao Vaticano II, os seus autores oferecem alguns interessantes estímulos. Um deles está, indubitavelmente, na relação entre o Vaticano II e o Concílio de Trento, vale dizer - para ser mais objetivo - na questão da efetiva validade, hoje, das tomadas de posição doutrinal (inclusive os anátemas) deste último, formuladas num horizonte exclusivamente contrarreformista. Por parecer de De Chirico, diante de um concílio incompleto, a Igreja católica não sentiu a necessidade de celebrar um segundo Concílio de Trento, um Trento II, mas advertiu sobre a urgência de celebrar um Vaticano II. Há cinquenta anos de sua celebração, que não tinha nenhuma intenção de contradizer o "paradigma tridentino", a teologia evangélica sugeriu que se convoque "um 'Concílio de Trento II' para abrir e modificar a estrutura contrarreformista da Igreja católica na ótica do Evangelho", 59 revisando, obviamente, os anátemas tridentinos.

A questão iniciada nesses termos não é de pouca importância, apoiando-se na legítima pergunta dos evangélicos - e, no fundo, de todos os hereges da Reforma - sob a influência do Concílio de Trento, de suas formulações doutrinais e de suas condenações, sobre a atual concessão católico-romana da doutrina e da experiência eclesial das igrejas e comunidades protestantes. As críticas e, sobretudo, as condenações tridentinas da Reforma são ainda atuais após o Vaticano II? ${ }^{60}$ 
Referem-se às igrejas e comunidades protestantes de hoje? ${ }^{61} \mathrm{Se}$ afirmativo, como se pode falar de um diálogo ecumênico sincero e construtivo entre tais igrejas e comunidades e a Igreja de Roma que, em dizê-lo abertamente, considera os seus semelhantes "cristãos hereges" e "excomungados"? Caso contrário, em base de que atos ou documento do Magistério se pode afirmar o fim de tais críticas e condenações?

Que não se trate de questões injustificadas e que a Igreja católica, o seu Magistério e a sua teologia forneçam uma resposta unívoca se é possível intuir já por ocasião da preparação e da publicação da Declaração conjunta sobre a doutrina da justificação (1998) entre a Igreja católico-romana e a Federação luterana mundial. ${ }^{62}$ Enquanto na Declaração se encontra mencionada, como ecumenicamente aceitável, a doutrina luterana do simul iustus et peccator, tal abertura é sentida no texto da Resposta da Igreja católica à Declaração conjunta entre a Igreja católica e a Federação luterana mundial em relação à doutrina da justificação, ${ }^{63}$ elaborado de comum acordo entre a Congregação para a doutrina da fé e o Pontifício conselho pela promoção da unidade dos cristãos. Referindo-se ao Concílio de Trento, o texto anota que a doutrina do simul iustus et peccator, assim como é explicada na Declaração, não é aceitável e que, por consequência, continua difícil ver como se possa afirmar que ela, no estado atual da apresentação, "não seja mexida em relação aos anátemas dos decretos tridentinos sobre o pecado original e sobre a justificação". ${ }^{64}$ Tal juízo foi em seguida retomado por não poucos teólogos católicos, os quais o acolheram como expressão de uma tomada de posição com autoridade e representatividade da Igreja católica em relação com a doutrina da Reforma. Mas o cardeal W. Kasper, então Presidente do Pontifício conselho pela promoção da unidade dos cristãos, foi "empurrado" para uma outra direção, quando escreveu que o problema do simul iustus et peccator, por poder ainda "trazer vantagem para uma posterior explicação e esclarecimento", ${ }^{65}$ foi substancialmente resolvido pela Declaração conjunta.

O caso da avaliação discordante da doutrina do simul iustus et peccator é só um exemplo de um estado conectado de coisas mais gerais, sim, com a questão da interpretação das fórmulas doutrinais e das considerações do Concílio de Trento, mas antes ainda com a questão da recessão e interpretação das fórmulas concretas normativo-doutrinais e das eventuais condenações de cada outro concílio do passado. Que valor tem hoje aquilo que foi formulado no passado por um concílio ecumênico? Não deveriam os novos concílios referir-se a respeito das 
formulações dos concílios anteriores, visto que se trata de acontecimentos com o máximo grau de consenso eclesial? Mas se esses nunca fizeram nada em relação a certas fórmulas concretas e declarações, e se não fizeram nem mesmo os respectivos papas, recorrendo às intervenções magisteriais tendo aquele nível de autoridade que poderia ser equiparado à autoridade da assembleia conciliar? Ou se pode, talvez, dar como pressuposto que certas declarações específicas, fórmulas e condenações dos concílios ecumênicos não valham mais pelo simples fato de não terem sido mais citadas pelos concílios e pelos papas posteriores? Uma coisa é certa: pensar que seja o decorrer do tempo e a consequente mudança da mentalidade eclesial que constituem os movimentos determinantes que guiam por si, automaticamente, a interpretação dos concílios significaria negar a Igreja e o seu Magistério vivo, uma tarefa de primeira importância: ocupar-se com cuidados permanentes do depositum fidei.

A exigência de um aperfeiçoamento de método de interpretação dos documentos dos concílios ecumênicos - e dos textos da doutrina católicoromana em geral - apresenta-se, hoje, como uma questão aberta que não pode ser subvalorizada. Propor uma solução clara e compartilhada resultará não só na continuação do diálogo ecumênico - enquanto permitirá irmãos não católicos orientar-se melhor no espaço da doutrina católica -, mas também na formulação de uma contribuição decisiva para o esclarecimento da vexata quaestio, resguardado o processo de interpretação de cada novo concílio e, no fundo, de cada novo ato do Magistério: aquela da continuidade e/ou descontinuidade entre o "novo" e o "passado" na Igreja, na sua doutrina e práxis sacramental, litúrgica e pastoral.

Recebido: 14/06/2014

Avaliado: 25/06/2014 